JEVTE: Journal of Electrical Vocational Teacher Education, Vol. 1, No. 2, Nopember 2021

\title{
EFEKTIFITAS PENGGUNAAN MODEL PEMBELAJARAN BERBASIS PRODUK TERHADAP PENINGKATAN MINAT WIRAUSAHA MAHASISWA
}

\author{
Mega Silfia Dewy ${ }^{1}$, Muhammad Isnaini ${ }^{2}$ \\ ${ }^{1,2}$ Pendidikan Teknik Elektro Fakultas Teknik Unimed \\ 1megasilfiadewy@unimed.ac.id, ${ }^{2}$ misnaini@unimed.ac.id
}

\begin{abstract}
Abstrak
Penelitian ini bertujuan untuk mendesktripsikan dan mengevaluasi efektivitas dari penerapan model pembelejaran bebasis produk untuk meningkatkan minat wirausaha mahasiswa. Dalam penerapan pembelajaran berbasis produk, mahasiswa diharapkan dapat meningkatkan keaktifannya, sehingga proses pembelajaran yang diikuti menjadi lebih bermakna. Melalui pembelajaran berbasis produk ini mahasiswa difasilitasi untuk mengembangkan minat wirausahanya dengan merencankan peluang-peluang usaha yang bisa dikembangkan dari produk yang dihasilkan dalam pembelajaran. Tujuan akhir pembelajaran dengan menerapakan model pembelajaran berbasis produk adalah menghasilkan mahasiswa yang aktif serta kreatif dalam proses pembelajaran sehingga dapat menghasilkan sebuah produk yang memiliki nilai jual sehingga bisa menciptakan peluang usaha. Penelitian ini menggunakan metode desktiptif kualitatif. Teknik pengumpulan data yang digunakan adalah melalui wawancara, observasi langsung, dokumentasi dan kuisioner. Hasil penelitian menunjukkan penerapan model pembelajaran berbasis produk efektif dalam meningkatkan minat wirausaha mahasiswa dengan terus menciptakan peluang berwirausaha melalui pembelajaran.
\end{abstract}

\section{Kata Kunci: Model Pembelajaran, Model Pembelajaran Berbasis Produk, Minat Wirausaha}

\begin{abstract}
This study aims to describe and evaluate the effectiveness of the application of product-based learning models to increase student entrepreneurial interest. In the application of product-based learning, students are expected to increase their activeness, so that the learning process that is followed becomes more meaningful. Through product-based learning, students are facilitated to develop their entrepreneurial interests by planning business opportunities that can be developed from the products produced in learning. The ultimate goal of learning by applying a product-based learning model is to produce students who are active and creative in the learning process so that they can produce a product that has a selling value so that it can create business opportunities. This study uses a qualitative descriptive method. Data collection techniques used are through interviews, direct observation, documentation and questionnaires. The results showed that the application of product-based learning models was effective in increasing student entrepreneurial interest by continuing to create entrepreneurial opportunities through learning.
\end{abstract}

\section{Keywords: Learning Model, Product Based Learning Model, Entrepreneurial Interest}

\section{PENDAHULUAN}

Pendidikan merupakan kebutuhan bagi setiap manusia dalam proses kehidupannya. Pendidikan juga memiliki peranan yang sangat penting dalam setiap kehidupan pribadi manusia, diantaranya untuk membangun karakter dan kepribadian serta berperan penting dalam mendewasakan manusia di sepanjang hidup dimana pun dan kapan pun. Pendidikan berpengaruh pada perkembangan mental, emosional, fisik, serta etika manusia. Peran penting pendidikan lainnya yaitu dalam peningkatan kualitas sumber daya manusia serta kemajuan dan pembangunan bangsa.

Pendidikan di Indonesia terbagi menjadi beberapa jenis dan jenjang pendidikan. Menurut UU UU Sisdiknas No 20 Tahun 2003 Pasal 15 salah satu jenis pendidikan di Indonesia yaitu pendidikan vokasi. Pendidikan vokasi merupakan sistem pendidikan tinggi yang bertujuan untuk mengarahkan peserta didiknya pada penguasaan keahlian terapan tertentu dengan tujuan mencapai tujuan pendidikan nasional. Pada pendidikan vokasi ini peserta didik diarahkan pada pengembangan keahlian terapan, adaptasi pada bidang pekerjaan tertentu dan juga mempunyai kemampuan dalam menciptakan peluang 
usaha. Pendidikan vokasi yang merupakan bagian dari sistem pedidikan nasioanl ini, memiliki perananan yang strategis untuk mewujudkan tenaga kerja yang kompeten, serta terampil dalam menciptakan peluang usaha. Suatu negara akan berpeluang memiliki pertumbuhan ekonomi yang tinggi apabila didukung dengan sumber daya manusia yang mempunyai: pengetahuan dan kemapuan dasar untuk terus beradaptasi dengan perubahan-perubahan yang terjadi di era globlisasi, peningkatan jenjang pendidikan, kemampuan dan keahlian dalam ilmu pengetahuan dan teknologi, serta kemampuan untuk selalu menghasilkan produk yang kreatif dan inovatif yang dapat bersaing dengan produk-produk lainnya di pasar global. Selain menghasilkan lulusan yang siap kerja di industry, pendiidkan vokasi juga dituntut untuk menghasilkan lulusan yang dapat menciptakan peluang kerja melalui pembelajaran yang memfasilitasi peserta didiknya agar kreatif dan inovatif dalam menumbuhkan peluang usaha.

Menghasilkan lulusan yang kreatif dan inofatif serta dapat bersaing di dunia usaha/industri merupakan bagian dari tugas pendidikan vokasi. Untuk itu pendidikan vokasi perlu merujuk kompetensi dan keahlian apa saja yang dibutuhkan dunia usaha/industri dalam mengembangkan kompetensi lulusan nya. Mata kuliah praktek merupakan salah satu mata kuliah yang sangat penting dan strategis dalam membentuk dan mengembangkan kompetensi peserta didik. Untuk itu sangat perlu dilakukan peningkatan mutu dalam proses pembelajaran praktek. Mata kuliah praktek merupakan mata kuliah yang bisa menjebatani mahasiswa untuk aktif dan kreatif selama proses pembelajaran, sehingga harus didukung oleh sumber dan model pembelajaran yang sesuai agar kreatifitas mahasiswa dalam kegiatan praktikum tersebut bisa ditingkatkan.

Salah satu mata kuliah praktek yang berpotensi dalam mencetak lulusan dengan kompetensi yang sesuai dengan kebutuhan dunia industri serta dapat menjebatani mahasiswa untuk aktif dan kreatif dalam menciptakan peluang usaha adalah mata kuliah praktek instalasi listik komersil. Tujuan utama pada pembelajan praktek ini adalah untuk membekali mahasiswa dengan kompetensi kerja dalam bidang instalasi listrik serta melatih mahasiswa untuk dapat mengembangkan diri setelah menyelesaikan pembelajarannya pada bidang ini. Namun pada kenyataanya, proses pembelajaran praktek instalasi yang berlangsung selama ini hanya berpusat kepada pencapaian kompetensi mahasiswanya dan belum mampu meningkatkan kreatifitas dan minat wirausaha mahasiswa yang dapat menciptakan peluang usaha. Untuk itu perlu dilakukan perubahan dan inovasi pembelajaran. Perubahan dan inovasi yang bisa diterapkan diantaranya yaitu dengan melakukan perubahan pada model pembelajaran yang digunakan selama ini.

Dalam pembelajaran pratek model pembelajaran yang tepat sangat diperlukan untuk menghasilkan outcome yang sesuai dengan tujuan pembelajaran, untuk itu perubahan model pembelajaran konvensional ke model pembelajaran baru seperti model pembelajaran berbasis produk dalam pembelajaran praktek diduga bisa mengatasi permasalahan tersebut, karena dengan model pembelajaran berbasis produk ini mahasiswa difasilitasi dan diarahkan untuk bisa berfikir aktif dan mengembangkan kreaktifitasnya sehingga dapat meningkatkan hasil belajar. Model pembelajaran berbasis produk dapat diartikan sebagai prosedur yang harus dilakukan pendidik untuk memfasiltasi peserta didiknya untuk dapat berperan aktif serta berpatisipasi dalam proses pembelajaran dengan tujuan mengasilkan peserta didik yang memiliki kompetensi untuk menghasilkan produk baik itu berupa barang/ jasa yang sesuai dengan kebutuhan dan memenuhi standar (Ganefri dkk , 2014). Model pembelajaran berbasis produk ini dapat memfasilitasi peserta didik untuk kreatif dan inovatif dalam penciptaan produk (barang/jasa) yang dibutuhkan dunia insdustri serta memilki nilai jual sehingga dengan model pembelajaran ini juga dapat meningkatkan minat wirausaha mahasiswa untuk menghasilkan keuntungan dari produk-produk yang dihasilkan melalui proses pembelajaran.

Minat wirausaha merupakan kecendrungan atau keinginan dalam diri untuk menghasilkan sebuah bidang usaha. Minat wirausaha juga merupakan keinginan individu untuk bekerja secara mandiri atau dapat membuka usaha sendiri. Munculnya minat wirausaha disebabkan oleh pengetahuan serta informasi baru mengenai dunia kewirausahaan yang diteruskan oleh keinginan untuk berpatisipasi dalam mencari pengalaman langsung sehingga timbul keinginan untuk meanfaatkan pengalaman yang dihasilkan tersebut. Kemapuan dalam memimpin, punya kemandirian, mampu bekerja sama dalam tim, berani mengabil resiko serta aktif dan inovatif merupakan ciri-ciri seseorang memiliki minat dan jiwa wirausaha. Untuk menghasilkan peserta didik yang memiliki jiwa dan minat wirausaha, dalam proses pembelajaran, peserta didik perlu difasilitasi, didorong serta dimobilisai menjadi wirausahawan yang berani dan tangguh.

Berdasarkan pemaparan di atas penting adanya penelitian untuk mengetahui adanya efektifitas dalam penggunaan model pembelajaran berbasis produk dalam meningkatkan minat wirausaha 
mahasiswa. Penelitian ini dianggap ada unsur keterbaruan dari penelitian sebelumnya karena minat berwirausaha digali melalui penerapan model pembelajaran berbasis produk dalam rangkaian prosedur yang sistematis (sintaks) model, yang dalam pelaksanaannya diikuti dengan praktik langsung, memproduksikan serta membuat Bussines Plan dari produk yang dihasilkan sehingga dapat menghasilkan peluang usaha yang bisa bersaing pada dunia usaha/industri.

\section{Model Pembelajaran}

Model pembelajaran merupakan sebuah perencanaan atau pola yang dapat dipedomani dalam merencanakan pembelajaran, model pembelajaran juga bisa dikatakan sebagai sebuah pendekatan pembelajaran yang digunakan, yang didalamnya terdiri dari tujuan pembelajaran, tahapan pembelajaran, lingkungan pembelajaran serta proses pengelolaaan kelas (Arends, 1997:7). Model pembelajaran adalah sebuah kerangka konsep yang berisikan langkah-langkah yang sistematis dalam pengelolaan pengalaman belajar peserta didik agar tujuan pembelajaran dapat tercapai. Model pembelajaran berfungsi sebagai pedoman bagi pendidik dalam merencanakan dan melaksanakan pembelajaran (Joyce \& Weil, 2003). Model pembelajaran merupakan sebuah pola yang digunakan sebagi panduan dalam merencanakan pembelajaran. panduan ini digunakan untuk menentukan atau merencanakan perangkatperangkat pembelajaran yang terdiri dari kurikulum, metode, media serta sumber-sumber belajar lainnya. Dari pemaparan di atas sebuah model pembelajaran dapat diartikan sebagai sebuah pola yang digunakan dalam proses pembelajaran serta merupakan sebuah pedoan yang digunakan dala rencanakan pembelajaran.

Model pembelajaran berfungsi sebagai pedoman bagi pendidik dalam merancang dan melaksanalan pembelajaran (Trianto, 2010:53). Pemilihan model pembelajaran yang tepat dipengaruhi oleh tujuan pembelajaran yang ingin dicapai serta kompetendi dari peserta didik itu sendiri. Model pembelaran terdiri dari tahapan-tahapan/ sintaks kegiatan yang dilakukan dalam membimbing dan mengorganisakan peserta didik dalam pembelajaran. Setiap model pembelajaran memiliki sintaks yang berbeda sesuai dengan tujuan akhir pembelajaran yang diinginkan. Model pembelajaran digunakan sebagai sumber rancangan proses pembelajaran, dimana kegiantan merancang proses pembelajaran tersebut akan menghasilkan rumusan kompetensi. Secara keseluruhan fungsi model pembelajaran adalah sebagai alat komunikasi bagi pendidik dalam melaksanakan proses pembelajaran yang bertujaun untuk mebantu dan memfasilitasi peserta didik untuk memiliki kompetensi yang diinginkan.

\section{Model Pembelajaran Berbasis Produk}

Model pembelajaran berbasis produk adalah sebuah prosedur pembelajaran yang dirancang secara terstruktur dan disesuaikan dengan standar kerja yang sesungguhnya untuk menciptakan produk, baik itu berupa barang atau jasa yang memenuhi standar pasar atau standar industri. Model pembelajaran berbasis produk ini menekankan pembelajaran yang fokus utamanya pada keahlian atau keterampilan peserta didik dalam melakukan kegiatan produksi barang atau jasa yang sesuai dengan standar dunia usaha/industri. Fokus utama dalam pembelajaran berbasis produksi adalah rencana kerja, langkah kerja yang sistematis serta hasil produk (barang/jasa) yang memiliki nilai jual atau memenuhi standar industri (Suryadi dan Yuza, 2009). Marlina (2010) menjelaskan bahwa proses pembelajaran berbasis produksi ini mempunyai aspek keterpaduan yang memiliki konsep kebermaknaan, yang artinya melalui proses pembelajaran berbasis produksi ini peserta didik bisa memahami konsep dan memahami makna dari pembelajaran yang didapat dari pengalaman langsung dalam mengerjakan proses produksi barang atau jasa. Ganefri dkk (2014) juga menjelaskan bahwa model pembelajaran berbasis produk ini didefiniskan sebagai prosedur atau langkah-langkah yang dilakukan peserta didik untuk memfasilitasi peserta didik untuk belajar aktif, berpartisipasi dan berinteraksi dengan orientasi kompetensi untuk menghasilkan produk yang sesuai dengan dunia industri. Sehingga dapat disimpulkan bahwa model pembelajaran berbasis produk adalah sebuah prosedur atau langkah kerja yang sistematis yang memiliki konsep kebermaknaan yang dapat memfasilitasi mahasiswa untuk belajar aktif dan partisipatif melalui pengalaman langsung menghasilkan produk baik itu barang/ jasa yang memiliki nilai jual atau memenuhi standar pasar atau dunia industri.

Dalam penerapannya, model pembelajaran berbasis produk ini dapat memfasilitasi peserta didik dalam pengembangan kompetensi seperti mengembangkan kemampuan berfikir, mengasah keterampilan melalui produksi barang/jasa, serta kemampuan berkerja sama dalam tim dalam pengerjaan sebuah produk. Model pembelajaran ini merupakan model pembelajaran aktif dimana peran peserta didik dalam proses pembelajaran sangatlah besar, seperti peran aktif peserta didik dalam 
membuat pertanyaan penting tentang produk yang akan dihasilkan, menganalisis kebutuhan alat dan bahan yang dibutuhkan selama proses produksi, serta peran aktif peserta didik untuk menguasai keterampilan yang didapatkan dalam proses produksi barang/jasa. Model pembelajaran berbasis produk ini merupakan penjabaran dari langkah-langkah atau sintaks dalam proses pembelajaran, yang mana sintaks dari model pembelajaran ini terdiri dari sembilan langkah atau sembilan tahapan yang dimulai dengan: pertama, menganalisis kurikulum serta karakteristik peserta didik untuk mendapatkan keseuaian model pembelajaran yang dikembangkan dengan tujuan kurikulum dan karakteristik dari peserta didiknya. Kedua, Mengidentifikasi dan menganalisis produk yang akan dibuat dalam pembelajaran. Ketiga, Memunculkan pertanyaan penting tentang produk. Keempat, memetakan pertanyaan seputar produk atau pertanyaan yang berhubungan dengan produk. Kelima, Menganalisis kebutuhan alat dan bahan yang dinutuhkan dalam membuat produk. Keenam, Membuat jadwal pelaksanaan pembuatan produk yang berfungsi sebagai acuan atau timeline dalam menghasilkan produk agar selesai tepat waktu. Ketujuh, Proses Pembuatan produk yaitu kegiatan dalam memproduksi atau menghasilkan produk dalam pembelajaran. Kedelapan, Melakukan evaluasi secara berkala agar produk yang dihasilkan sesuai dengan standar industry atau standar dunia usaha dan yang terakhir yaitu, membuat perencanaan bisnis (business plan) untuk pemasaran produk yang telah dihasilkan dalam pembelajaran.

\section{Minat Wirausaha}

Minat dapat diartikan sebagai suatu hal yang berhubungan dengan kepribadian seseorang seperti keinginan diri, gairah atau kecendrungan terhadap sesuatu. Untuk mengetahui minat dapat dilihat melalui: (1) pertanyaan yang diberikan, seperti apa hal yang lebih disukai peserta didik dibandingkan hal yang lainnya, dan (2) partisipasi peserta didik dalam sebuah aktifitas, dimana jika peserta didik mempunyai minat pada suatu hal/ subjek maka mereka akan memberikan perhatian yang lebih pada subyek tersebut ( Slameto, 2003:180). Ajzen (2005) mengatakan bahwa minat merupakan sebuah intensi/keinginan yang mana akan diwujudkan dalam bentuk tindakan pada suatu waktu dan kesempatan yang tepat.

Wirausaha dapat diartikan sebagai seseorang yang memiliki kemampuan untuk: mengorganisasikan dan menjalankan sebuah usaha, memiliki kreratifitas yang tinggi, dapat membaca peluang baru untuk usaha dan memiliki kemampuan untuk menghadapi resiko dalam sebuah usaha untuk menghasilkan keuntungan dan kesuksesan dalam usahanya. Minat wirausaha adalah perhatian lebih yang diberikan kepada sebuah usaha karena rasa ketertarikan / suka serta keinginan lebih untuk mengetahui dan mempelajari wirausaha tersebut (Mustofa, 2014:11). Munculnya minat untuk berwirausaha disebabkan oleh pengetahuan tentang wirausaha, keinginan untuk berpatisipasi dalam mendapatkan pengalaman yang pada akhirnya menimbulkan keinginan untuk memberikan perhatian lebih pada pengalamana yang didapat serta memiliki kemampuan untuk menghadapi resiko untuk mendirikan usaha sendiri dengan keterampilan membaca peluang yang ada atau peluang yang bisa dimanfaatkan.

Ciri-ciri minat wirausaha dapat dilihat dari rasa suka atau tertarik seseorang untuk mendirikan sebuah usaha. Minat wirausaha seseorang tidak serta merta didapatkan dari lahir, melainkan bisa dikembangkan dengan pendidikan dan pelatihan. Salah satu faktor yang mempengaruhi minat wirausaha adalah soft skills karena seorang wirausahawan membutuhkan karakter dan keterampilan yang kuat dalam membangun usahanya. Minat wirausaha juga dapat diartikan sebagai keinginan seseorang untuk sepenuhnya menjalankan aktivitas usaha/ bisnis dengan memaksimalkan semua kemampuanya pada usaha tersebut. Hisrich et,al (2008) menjelaskan bahwa munculnya minat wirausaha seseorang disebabkan oleh : perasaan yakin mempunyai kemampuan dan kapasitas untuk menjadi wirausaha yang berhasil dan perasaan senang dalam menjalankan kegiatan usaha. berdasarkan pendapatpendapat yang telah dijabarkan sebelumnya, dapat ditarik kesimpulan bahwa minat wirausaha itu adalah sebuah kecendrungan, rasa tertarik, keinginan, dan kemauan bekerja keras dalam mencukupi kebutuhan hidup dengan kemampuan untuk menghadapi resiko serta kemauan untuk selalu belajar dari pengalaman sehingga dapat memanfaatkan peluang untuk kesuksesan usahanya.

Menurut para ahli, ada beberapa faktor yang mempengaruhi individu menjadi wirausahawan diantaranya: keinginan untuk menjadi wirausaha bisa datang dari teman, keluarga dan sahabat, hal ini disebabkan karena ide wirausaha didapatkan dari hasil diskusi bersama mengenai ide wirausaha, masalah yang mungkin dihadapi dalam berwirausaha serta cara mengatasinya (Alma, 2013:7). Basrowi (2014:64) menjelaskan minat wirausaha dipengaruhi oleh dua faktor yaitu: Pertama, Faktor internal 
yang merupakan, segala hal yang berasal dari dalam diri seseorang seperti pikiran dan emosi yang dapat mempengaruhi minat berwirausaha. Faktor internal ini terdiri dari: (1) Motivasi, merupakan daya pengerak utama dalam diri seseorang dalam mencapai tujuan. Motivasi juga merupakan proses psikologis yang mendasari perubahan reaksi dari dalam diri manusia untuk mencapai tujuan yang diinginkan. Motivasi merupakan dorongan/ kekuatan yang berasal dari dalam diri manusia yang mengerakkan manusisa untuk mewujudkan tingkah laku pada pencapaian suatu tujuan, (2) Kemampuan, merupakan kesanggupan/ kekuatan seseorang pada suatu bidang. Kemampuan ini dapat diperoleh melalui pendidikan dan pelatihan baik formal maupun non formal, (3) Rasa senang, merupakan perasaan suka atau tertarik pada hal tertentu yang berasal dari dalam diri seseorang. Perasaan senang terhadap hal atau bisang usaha tertentu akan menimbulkan minat wirausaha. Factor yang kedua yaitu, faktor eksternal yaitu faktor yang dapat mempengaruhi minat wirausaha asalnya dari luar diri individu. Faktor eksternal terdiri dari: (1) Keluarga. merupakan salah satu faktor yang sangat penting dalam mepersiapkan anak untuk mencapai masa depan yang baik. Dorongan dari keluarga dan orang tua dapat mempengaruhi seseorang untuk menumbuhkan minat wirausaha, selain itu latar belakang keluarga juga merupakan faktor lahirnya minat wirausaha seseorang, (2) Lingkungan masyarakat, merupakan salah satu faktor yang dapat mempengaruhi minat wirausaha seseorang melalui nilai-nilai yang ada di dalam masyarakat, seperti: iklim pergaulan dengan teman-teman sebaya, serta nilai nilai yang didapatkan dari surat kabar televisi, media social dan lainnya, (3) Lingkungan sekolah, merupakan faktor yang sangat berpotensi dalam mendorong peserta didik dalam menumbuhkan dan mengembangkan minat berwirausaha.

\section{METODE}

Dalam penilitian ini, jenis penelitian yang digunakan adalah penelitian deskriptif kualitatif. Penelitian deskriptif kualitatif ini merupakan sebuah prosedur untuk penelitian yang menghasilkan data deskriptif berbentuk kata-kata, baik itu secara tertulis atau lisan yang didapatkan dari pengamata kegiatan atau prilaku dari subjek yang diteliti, (Bogdan dan Taylor dalam Moleong 2010:4). Penelititan deskkriptif ini bertujuan untuk membuat sebuah gambaran/deskripsi yang dilakukan secara sistematis serta menjelaskan korelasi antara kegiatan yang diamati. Metode penelitian kualitatif merupakan penelitian yang dilandasi oleh filsafat positivisme, yang digunakan untuk penilitian dengan objek alamiah (lawan dari eksperimen), dimana dalam penelitian ini peneliti merupakan instrument kunci. (Sugiyono, 2015:15). Pengambilan sampel dilakukan dengan purposive dan snowball, Teknik penggambungan dengam triangulasi serta analisisi datanya bersifat induktif/ kualitatif.

Subjek dalam penelitian ini adaalah mahasiswa praktek teknik instalasi listrik yang pembelajaran prakteknya menggunakan model pembelajaran berbasis produk dengan jumlah 35 orang. Penelitian ini dimaksudkan untuk melihat efektivitas peningkatan minat wirausaha mahasiswa yang menggunakan model pembelajaran berbasis produk.

Prosedur dalam mengumpulkan data dilakukan melalui metode observasi, angket serta wawancara. Observasi atau pengamatan dilakukan dengan nelihat reaksi subjek (peserta didik) dalam pembelajaran menggunakan model pembelajaran berbasis produk pada matakuliah praktek instalasi listrik komersil. Selanjutnya dilakukan penyebaran angket minat yang telah uji validitas dan realibilitasnya sekaligus diikuti dengan kegiatan wawancara (interview) penelitian secara tidak terstruktur terhadap subjek untuk menmbah akurasi data yang didapat melalui observasi guna semakin memperkuat dan dapat memberikan keterangan data observasi yang semakin jelas. Angket disebarkan 2 kali, sebelum dan sesudah pembelajaran dengan menggunakan mode berbasis produk untuk melihat peningkatan minat kewirausahaan mahasiswa. Angket yang diberikan dalam bentuk pertanyaanpertanyaan berkaitan dengan minat mahasiswa untuk berwirausaha.

Dalam mengukur minat berwirausaha mahasiswa menggunakan dua indikator yaitu faktor internal dengan 3 sub indikator dan faktor eksternal dengan 3 sub indikator. Sub indikator motivasi diungkap dengan 12 pernyataan, sub indikator kemampuan diungkap dengan 10 pernyataan, subindikator senang diungkap dengan 7 pernyataan, subindikator keluarga dengan 5 pernyataan, subindikator lingkungan masyarakat dengan 3 pernyataan dan subindikator lingkungan sekolah dengan 3 pernyataan. Semua pernyataan diukur dengan skala Likert yang terdiri dari skala 1- 4 poin yaitu dengan nilai sangat setuju 4, setuju dengan nilai 3, tidak setuju dengan nilai 2 dan sangat tidak setuju dengan nilai 1 , untuk pertanyaan yang positif. Pertanyaan negatif nilainya berbalik dari pertanyaan positif. Jawaban responden terhadap variabel penelitian sangat beragam dari skala yang telah ditentukan.

Instrument yang digunakan dalam pengumpulan data penelitian ini adalah: (1) lembar observasi sebagai acuan dalam mengamati reaksi untuk memperoleh informasi. (2) lembar wawancara sebagai 
acuan dalam mengajukan pertanyaan pada para responden guna memperkuat data yang sudah didapat saat observasi, dan (3) lembar angket yang dibagikan pada mahasiswa untuk mengetahui peningkatan minat wirausaha mahasiswa, angket yang dibagikan disini adalah angket yang telah melalui uji validitas dan realibilitas. Pada uji didapatkan bahwa dari 40 butir soal, didapatkan 7 butir soal yang tidak valid, sehingga setelah dilakukan revisi, angket yang disebarkan berjumlah 33 item. Dalam penelitian ini digunakan analisis data berupa analisis deskripftif menggunakan presentase. Analisis deskriptif dilakukan dengan cara mebuat deskripsi atau membuat gambaran mengenai dara yang telah dikumpulkan dengan apa adanya tanpa bermaksud untuk membuat kesimpulan umum/ generalisasi (Sugiyono, 2007:207). Data dalam penilitian ini dihitung dengan melihar harga rata-rata (Mean / Me). harga rata-rata adalah Teknik penjelasan kelompok berdasarkan nilai rata-rata kelompok tersebut. Nilai rata-rata (mean) dapat dihiutng dengan cara, seluruh data yang ada di dalam kelompok tersebut dibagi dengan jumlah seluruh peserta yang ada. Nilai rerata ini dapat dirumuskan dengan persamaan di bawah ini:

Dimana, $\mathrm{Me}=$ Mean $=$ Harga rata-rata

$$
\mathrm{Me}=\frac{\sum f(x)}{n}
$$

$\mathrm{f}(\mathrm{x})=$ Jumlah perkalian antara besar nilai $\mathrm{x}$ dengan frekuensi

$\mathrm{n} \quad$ = Jumlah sampel

\section{HASIL DAN PEMBAHASAN}

Tujuan dari penelitian ini adalah untuk melihat efektifitas dari peningkatan minat wirausaha mahasiswa yang menggunakan model pembelajaran berbasis produk pada pembelajaran praktek. Pada awal kegiatan, sebelum diadakannya pembelajaran menggunakan model pembelajaran berbasis produk, mahasiswa yang akan mengikuti mata kuliah dalam penelitian ini diberikan angket minat wirausaha di awal yang disertai wawancara dan observasi untuk melihat sejauh mana minat wirausaha yang dimiiliki agar bisa dibandingkan dengan minat wirausaha mahasiswa setelah mengikuti pembelajaran berbasis produk.

Dari hasil observasi dan wawancara didapatkan bahwa mahasiswa belum terlalu tertarik untuk melakukan wirausaha dari hasil pembelajaran praktek mereka selama ini. Hal ini dikarenakan (1) pembelajaran praktek selama ini hanya bertujuan untuk pencapaian kompetensi, (2) pembelajaran praktek mahasiswa selama ini belum diarahkan kepada pembuatan produk baik itu barang atau jasa, dan (3) mahasiswa belum mengerti bagaimana merencanakan sebuah usaha yang sesuai dengan bidang yang mereka pelajari. Dari hasil penyebaran angket pertama, berdasarkan hasil analisis reratanya didapatkan bahwa minat mahasiswa untuk berwirausaha masih sangat rendah hal ini terlihat bahwa untuk inidikator internal yang berkaitan dengan minat dari dalam diri mahasiswa seperti motivasi, kemampuan dan perasaan senang rata-rata nya hanya terletak pada rentang nilai 42 - $51 \%$ saja, sedang kan untuk faktor eksternal yaitu: lingkungan keluarga, sekolah serta masyarakat berada pada rentang nilai $59-66 \%$, hasil rata-rata angket minat mahasiswa sebelum menggunakan model pembelajaran berbasis produk dapat dilihat pada Tabel.1 berikut:

Tabel. 1 Hasil Rata-Rata Angket 1

\begin{tabular}{|c|c|}
\hline Indikator & Rata-Rata (\%) \\
\hline 1 & 43.39 \\
\hline 2 & 51.17 \\
\hline 3 & 42.76 \\
\hline 4 & 59.55 \\
\hline 5 & 65.87 \\
\hline 6 & 57.33 \\
\hline
\end{tabular}




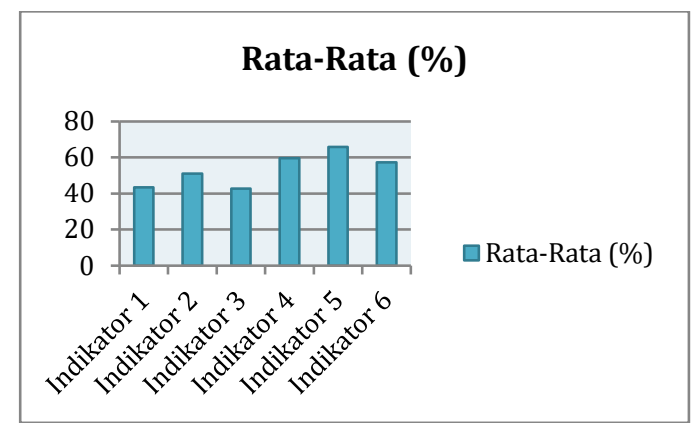

Gambar 1. Hasil rata-rata angket 1

Pada mata kuliah praktek instalasi listrik komersil ini model pembelajaran yang digunakan merupakan model pembelajaran berbasis produk yang terdiri dari 9 sintaks, yaitu:

1) Menganalisis kurikulum dan karakteristik peserta didik (mahasiswa)

Kegiatan yang dilakukan pada tahapan ini adalah menentukan tujuan pembelajaran, mengetahui kemampuan belajar mahasiswa, menentukan materi yang sesuai dengan pembelajaran berbasis produk

2) Identifikasi dan analisis produk

Kegiatan yang dilakukan pada tahapan ini adalah menentukan standar kompetensi minimal mata kuliah, yang bertujuan untuk tercapainya kompetensi yang diharapkan melalui produk yang dirancang, mengetahui kesesuaian produk dengan kebutuhan masyarakat, ini dimaksudkan agar produk yan dibuat dapat terpakai dan menjawab masalah yang ada dimasyarakat.

3) Membuat pertanyaan penting tentang produk

Kegiatan pada tahapan ini dapat membantu peserta didik dalam berfikir dan mengeksplorasi kemampuannya, sehingga dapat lebih mudah memahami materi dan konsep yang berhubungan dengan produk yang akan dibuat

4) Pemetaan Pertanyaan

Pada tahapan ini kegiatan yang dilakukan adalah mengelompokkan pertanyaan yang dimunculkan oleh mahasiswa terkait dengan aspek: kegunaan produk, proses pembuatan produk, unjuk kerja produk.

5) Menganalisis kebutuhan alat dan bahan dari produk yang akan dibuat

Dalam langkah ini peserta didik dapat menganalisis serta menentukan apa saja alat dan bahan yang dibutuhkan dalam menghasilkan produk berdasarkan masukan dan berbagai pertanyaan seputar produk yang akan dibuat, tentunya setelah memperoleh informasi dari apa saja alat dan bahan yang dibutuhkan sangat penting bagi peserta didik untuk mengetahui fungsi, konsep dari alat dan bahan yang digunakan

6) Pembuatan jadwal pelaksanaan pembuatan produk

Tahapan pembuatan jadwal pembuatan produk ini terdiri dari: menentukan jenis aktifitas pada pembuatan produk, yang artinya kegiatan mengetahui kegiatan apa yang akan dilakukan pada saat pembuatan produk, menentukan jadwal proses pengerjaan produk sampai selesai, bersama secara kolaboratif menentukan kapan mulai dan kapan selesai pengerjaan produk, mengetahui fasilitas pendukung dalam pembuatan produk, disamping mengetahui alat dan bahan yang dibutuhkan juga sangat penting mengatahui fasilitas pendukung seperti peralatan uji coba dan kalibrasi dan semua fasilitas diluar alat dan bahan yang tersedia (termasuk pemenuhan komponen yang tidak tersedia di jurusan), menentukan kelompok kerja pembuatan produk, pembuatan produk ini dilakukan berkelompok berdasarkan tingkat kerumitan produk yang akan dibuat.

7) Proses pembuatan produk

Produk yang dihasilkan pada tahapan ini berupa produk (barang/jasa) yang mempunyai nilai jual dan nilai guna/manfaat bagi masyarakat, sehingga bisa menjawab kebutuhan atau permasalahan yang ada di masyarakat. Tahap proses pembuatan produk ini dimulai dengan aktifitas: mempersiapkan lingkungan kerja untuk pembuatan produk, artinya pelaksanaan pembuatan produk dapat dilaksanakan apabila semua perlengkapan seperti alat dan bahan yang dibutuhkan sudah tersedia dengan lengkap, kondisi ini perlu menjadi perhatian agar proses pembuatan produk tidak terkendala, mempersiapkan panduan pembuatan produk baik modul maupun jobsheet berbasis produk, untuk lebih terarahnya pelaksanaan pembuatan produk ketersediaan perangkat 
pembelajaran baik modul maupun jobsheet sudah tersedia, pembuatan produk sesuai dengan jadwal yang telah dirancang sebelumnnya.

8) Evaluasi secara berkala

Evaluasi yang dilakukan pada tahapan ini berupa penilaian yang dilakukan secara holistic dari awal sampai akhir proses pembuatan produk. Pada tahapan ini yang dilakukan adalah mempersiapkan rubrik penilaian aktivitas pembuatan produk oleh instruktur, melalui rubrik penilaian dapat dinilai secara lebih akurat, disamping itu juga membuat catatan seluruh proses pembuatan produk oleh peserta didik, tahapan dalam proses pembuatan penting untuk dicatat sehingga alur proses pembuatan dan kendala dapat terlihat dari catatan pembuatan produk. kemudian, Melakukan uji coba produk yang sudah selesai dibuat, produk yang sudah berhasil dibuat tentunya harus sesuai dengan standar kebutuhan masyarakat, pasar dan dunia industri.

9) Pembuatan business plan

Pembuatan perencanaan bisnis pada model pembelajaran berbasis produk ini dirancang untuk memberikan gambaran dan deskripsi tentang suatu produk. Business plan yang dibuat mampu memberikan gambaran tentang aspek kewirausahaan baik itu mengenai keunggulan dari produk, harga produk, kompetitor produk dan serta cara pemasaran produk tersebut, sehingga dengan melaksanaan pembelajaran menggunakan model pembelajaran berbasis produk ini, peserta didik disamping mampu menghasilkan produk yang dibutuhkan dimasyarakat juga dapat mengembangkan jiwa kewirausahaan. Business Plan pada pengembangan model pembelajaran berbasis produk ini terdiri dari: menyusun ringkasan, membuat deskripsi produk, membuat analisis pasar, menyusun perencanaan produksi, dan menyusun perencanaan keuangan.

Selama pembelajaran praktek menggunakan model pembelaran berbasis produk, dilakukan kembali observasi mengenai perubahan aktifitas yang dialami mahasiswa. dari hasil observasi terlihat bahwa ada peningkatan aktifitas mahasiswa selama proses pembelajaran. aktivitas mahasiswa yang diamati terdiri dari lima aspek yaitu melakukan diskusi kelompok untuk menjawab rumusan masalah, melakukan kegiatan praktikum sesuai dengan langkah kerja dan mampu membuktikan hipotesis yang telah dirumuskan, terlihat aktif dalam kegiatan praktikum dan bekerjasama dengan anggota kelompok, mengamati hasil kegiatan praktikum dan menganalisis hasil pengamatan dengan benar, membuat kesimpulan yang sesuai dengan hasil kegiatan praktikum.

Setelah pembelajaran menggunakan model berbasis produk ini, mahasiswa kembali diminta mengisi angket minat wirausaha yang disertai dengan wawancara. Dari hasil wawancara didapatkan hasil bahwa mahasiswa lebih tertarik untuk mengembangkan ide wirausaha mereka karena melalui pembelajaran dengan model ini mereka terlatih untuk berfikir aktif, kreatif dan inovatif dalam mengembangkan ide-ide baru untuk wirausaha. Dalam pembelajaran ini mereka juga lebih memahami analisis pasar karena dengan pembelajaran ini mereka dilatih untuk merencanakan usaha mereka dari produk yang dihasilkan dalam pembelajaran melalui rancangan business plan. Dari hasil penyebaran angket kedua didapatkan data sebagai berikut:

Tabel. 2 Hasil Rata-Rata Angket 2

\begin{tabular}{|c|c|}
\hline Indikator & Rata-Rata (\%) \\
\hline 1 & 78.97 \\
\hline 2 & 83.46 \\
\hline 3 & 87.33 \\
\hline 4 & 85.55 \\
\hline 5 & 72.24 \\
\hline 6 & 80.35 \\
\hline
\end{tabular}




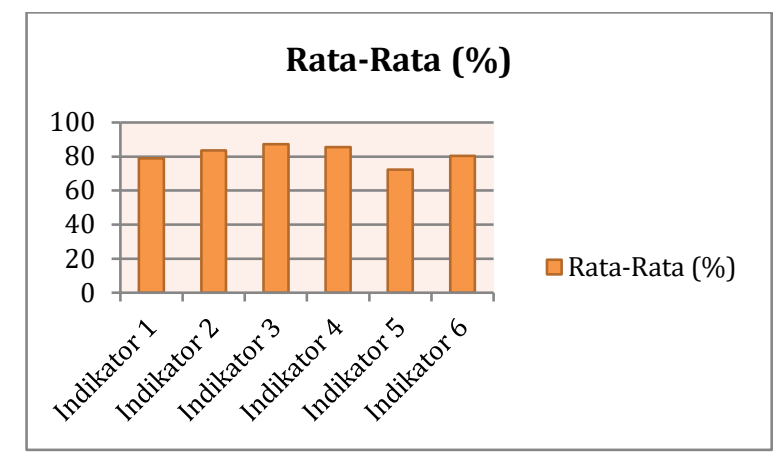

Gambar 2. Hasil rata-rata angket 2

Dari hasil penyebaran angket yang kedua didapatkan hasil yaitu terdapat peningkatan minat wirausaha mahasiswa setelah mengikuti pembelajaran praktek dengan model pembelajaran berbasis produk. Hal ini dapat dilihat dari nilai rata-rata yang diperoleh dimana pada indikator 1, rata-rata yang didapat pada uji angket I hanya sebesar 43,39 \% sedangkan pada uji angket II rata-rata yang diperoleh sebesar 78,97 \%, untuk indikator 2 rata-rata yang diperoleh pada uji angket I hanya sebesar 51,17\% sedangkan pada uji angket II rata-rata yang diperoleh sebesar $83,46 \%$, untuk indikator 3 rata-rata yang diperoleh pada uji angket I hanya sebesar $42,76 \%$ sedangkan pada uji angket II rata-rata yang diperoleh sebesar 87,33\%, untuk indikator 4 rata-rata yang diperoleh pada uji angket I hanya sebesar 59,55\% sedangkan pada uji angket II rata-rata yang diperoleh sebesar $85,55 \%$, untuk indikator 5 rata-rata yang diperoleh pada uji angket I hanya sebesar $65,87 \%$ sedangkan pada uji angket II rata-rata yang diperoleh sebesar 72,24 \%, untuk indikator 6 rata-rata yang diperoleh pada uji angket I hanya sebesar 57,33\% sedangkan pada uji angket II rata-rata yang diperoleh sebesar $80,35 \%$.

Dari kedua uji coba angket 1 dan uji coba angket ke 2 dapat dilihat bahwa ada peningkatan minat wirausaha mahasiswa yang telah mengikuti pembelajaran praktek menggunakan model pembelajaran berbasis produk, dimana dari nilai rata-rata untuk setiap indikator pada uji coba angket 1 dan uji coba angket 2 mengalami peningkatan. Peningkatan minat mahasiswa setelah penggunaan model pembelajaran berbasis produk ini dapat dilihat pada Gambar 3 berikut:

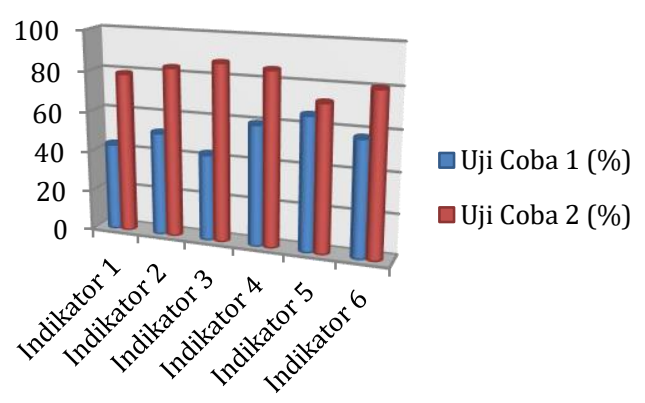

Gambar 3. Peningkatan minat wirausaha mahasiswa

\section{PENUTUP}

\section{Simpulan}

Pembelajaran praktek dengan menggunakan model pembelajaran berbasis produk efektif meningkatkan minat wirausaha mahasiswa karena dengan model pembelajaran ini mahasiswa difasilitasi untuk dapat aktif, kreatif serta inovatif dalam pembelajaran sehingga bisa menimbulkan minat mahasiswa dalam berwirausaha. Model pembelajaran yang digunakan ini merupakan model pembelajaran aktif, yang juga dilengkapi dengan komponen pendukung seperti satuan acara perkuliahan, modul berbasis produk, jobsheet praktikum berbasis prosuk serta panduan penggunaan pengguan model pembelajaran. 


\section{Saran}

Dalam penelitian yang dilakukan ini hanya terbatas pada beberapa pertemuan untuk menghasilkan suatu produk, diharapkan pada penelitian selanjutnya penelitian ini bisa lebih dikembangkan untuk menghasilkan beberapa produk dalam pembelajaran. Bagi mahasiswa yang menggunakan model pembelajaran berbasis produk ini diharapkan dapat menggali lagi potensi dirinya, sehingga dapat mengembangkan keterampilan, keahlian serta kreatifitasnya dalam pembelajaran, sehingga dapat menghasilkan produk/alat lainnya dan mampu memasarkan produk/alat yang telah dihasilkan.

\section{DAFTAR PUSTAKA}

Ajzen, I. (2005). Attitudes, personality and behavior. New York: Open University Press.

Arends, Richard. (1997). Classroom instructional management. New York: The McGraw-Hill Company.

Basrowi. (2016). Kewirausahaan: untuk perguruan tinggi. Bogor: Ghalia Indonesia.

Ganefri, Kusumaningrum, I., \& Hidayat, H. (2014). Production Based Learning: An Instructional Design Model in The Context of Vocational Education and Training (VET). Global Journal of Scince Frontier Research (GJSFR) Vol 14 Issue 3, ISSN. Online: 2249-4626, Print: 0975-5896 Iskandar, B. (2001). Kewirausahaan. Bandung: Sinar Baru.

Iskandar. (2012). Efektivitas Pendidikan Kewirausahaan dalam Mengembangkan Intensi Kewirausahaan. Disertasi. Sekolah Pascasarjana Universitas Pendidikan Indonesia.

Joye, W., \& Weil, M. (2003). Models of teaching (Fifth ed). New Delhi: Prentie-Hall of India Private Limited.

Marlina. (2010). Pengembangan Model Pelatihan Berbasis Produksi pada Pendidikan Vokasional. Makalah disajikan dalam Seminar International, APTEKINDO. UPI Bandung

Moleong, L.J. (2007). Metode penelitian kualitatif. Bandung: PT. Remaja Rosdakarya Offset.

Slameto. (2003). Belajar dan faktor-faktor yang mempengaruhinya. Jakarta: Rineka Cipta.

Sugiyono. (2007). Statistik untuk penelitian. Bandung: Alfabeta

Sugiyono. (2015). Metode penelitian kuantitatif, kualitatif dan R\&D. Bandung: Alfabeta.

Suryadi, Dedi \& Yuza, A.A. (2009. Model Pembelajaran Berbasis Produksi dengan Pendekatan Asesmen Portofolio pada Perkuliahan Praktik Kerja Bangunan. Jurnal Penelitian, (Online), Volume 9, Nomor 1, http://www.jurnal.upi.edu/file/Dedy_Suryadi.pdf.

Trianto. (2009). Mendesain model pembelajran inovatif-progresif. Jakarta: Kencana

Trianto. (2010). Model pembelajaran terpadu. Jakarta: Bumi Aksara 